Petit, R. J., BAhrman, N. and BARAdAT, P. (1995): Comparison of genetic differentiation in maritime pine (Pinus pinaster Ait.) estimated using isozyme, total protein and terpenic loci. Heredity 75: 382-389.

Petit, R. J., El-Mousadik, A. and Pons, O. (1998): Identifying populations for conservation on the basis of genetic markers. Conservation Biology 12: 844-855.

Raffin, A. (1999): Pin maritime. Pp. 50-51. In: Tessier dU Cross, E. (ed.). Conserver les ressources génétiques forestières en France. MAP-BRG, Commission des Ressources Génétiques Forestières, INRA-DIC, Paris.

RAYMOND, M. and RousseT, F. (1995): GENEPOP (version 1.2): Population genetics software for exact tests and ecumenicism. J. Hered. 86: 248-249.

Ribeiro, M. M., Plomion, C., Petit, R. J., Vendramin, G. G. and SzMIDT, A. C. (2001): Variation in chloroplast single-sequence repeats in Portuguese maritime pine (Pinus pinaster Ait.) Theor. Appl. Genet. 102: 97-103.

Rogers, D. L. and LEDIG, F. T. (eds.) (1996): The status of temperate North American Forest Genetic Resources. Report 16. University of California, Genetic Resources Conservation Program, Davis, California.

Rothe, G. M. (1994): Electrophoresis for enzymes: laboratory methods. Springer Verlag, Bertin-Heidelberg, 307 pp.

Salvador, L., AlíA, R., Agúndez, D. and Gil, L. (2000): Genetic variation and migration pathways of maritime pine (Pinus pinaster Ait.) in the Iberian Peninsula. Theor. Appl. Genet. 100: $89-95$.
SAvolainen, O. (2000): Guidelines for gene conservation based on population genetics. Pp. 100-109. In: KrishNAPILLAY, B. et al. (eds.). Proceedings of the XXI IUFRO World Congress, Malaysian XXI IUFRO World Congress Organising Committee, Malaysia.

SkouRI, M. (1994): Les dégradations du milieu et les mesures de protection. CR Acad. Agri. Fran. 80: 49-82.

TomASELLI, R. (1976): La dégradation du maquis méditerranéen. Pp. 34-75. In: Forêts et maquis méditerranéens: écologie, conservation et aménagements. Note Technique MAB 2. UNESCO, Paris.

Tremblay, M. and Simon, J. P. (1989): Genetic structure of populations of White spruce (Picea glauca) at its northern limit of distribution in nouveau-Québec. Can. J. For. Res. 19: 1371-1379.

WeIR, B. S. (1990): Genetic Data Analysis. Sinauer, Sunderland, MA

YeH, F. C. and LaYTon, C. (1979): The organization of genetic variability in central and marginal population of lodgepole pine (Pinus contorta ssp. latifolia). Can. J. Genet. Cytol. 21: 487-503.

Yeh, F. C., Yang, R.-C., Boyle, T., Ye, Z.-H. and MaO, J. X. (1997): POPGENE, the user-friendly shareware for population genetic analysis. Molecular Biology and Biotechnology Centre, University of Alberta, Canada.

\title{
Chloroplast DNA Variation in Some Representatives of the Asian, North American and Mediterranean Firs (Abies spp)
}

\author{
By A. KormutaK ${ }^{1 *}$, B. Vookova ${ }^{1)}$, B. Ziegenhagen ${ }^{2)}$, H. Y. Kwon ${ }^{3)}$ and Y. P. HonG ${ }^{3)}$
}

(Received $30^{\text {th }}$ January 2004)

\begin{abstract}
Using PCR-RFLP analysis, a comparative study on the restriction site polymorphism within 8 genes and regions of the Abies chloroplast DNA has been conducted covering 15 Asian, 6 North American and 7 Mediterranean species. A variable degree of divergence was observed among individual species of a given region as well as between geographical groups. A group of the Mediterranean firs, consisting of closely related species, differed profoundly from both Asian and North American representatives. Although a higher level of restriction site variants was detected among the Asian firs, two thirds of them were allocated to the difference between $A$. mariesii and the other Asian firs. The North American species exhibited the highest level of polymorphism resulting in several subgroups on a cladogram. At the individual species level, the Asian species $A$. mariesii and the North American species A. lasiocarpa

\footnotetext{
1) Institute of Plant Genetics and Biotechnology, Slovak Academy of Sciences, Akademicka 2, P.O.Box 39A, SK-950 07 Nitra, Slovak Republic.

2) Philipps-Universität Marburg, Fachbereich Biologie, Naturschutzbiologie, Karl-von-Frish-Strasse, D-35032 Marburg, Germany.

$\left.{ }^{3}\right)$ Korea Forest Research Institute, Dpt. of Forest Genetic Resources, Genetic Resources Division, 44-3 Omokchun-dong, Kwonsun-ku, Suwon 441-350, Kyunggi-do, Republic of Korea.

*) Corresponding author (e-mail: nrgrkorm@savba.savba.sk)
}

diverged conspicuously from their counterparts in their respective regions. The results of restriction site polymorphism analysis are discussed with ragard to crossability and taxonomic status of individual species.

Key words: Abies, chloroplast DNA, restriction site variation, relationships, species differentiation.

\section{Introduction}

The genus Abies is a prominent representative of the Pinaceae in Northern Hemisphere. According to the taxonomic account by LIU (1971) the genus comprises 39 species, 23 varieties and 8 natural hybrids between sympatric species growing in different parts of the world. A more recent classification FARJON and RUSHFORTH (1989) proposed the existence of as many as 49 species, 23 varieties and 1 natural hybrid in Abies.

Based on the karyological evidence of SAx and SAx (1933) and the crossability data by ROHMEDER and EISENHUT (1961), a close genetic relationship within the genus has been suggested (Kiellander, 1962; KlaeHN and Winieski, 1962). Extensive experiments with artificial cross-pollination of Abies spp. have however only partially validated this conclusion. A high degree of mutual crossability has been proved unequivocally only among the Mediterranean firs (GREGuss, 1984; KORMUTAK, 
1985). On the other hand, the North American representatives of Abies have been shown to be reproductively isolated not only from the Mediterranean firs but also to a high degree among themselves (Mergen et al., 1964; HAWLEY and DeHAYES, 1985; CRITCHFIELD, 1988). These findings significantly weakened the hypothesis of a close genetic affinity among Abies species.

Another line of evidence supporting profound differentiation within the genus has been provided recently by the restriction fragment length polymorphisms (RFLP) analysis of Abies chloroplast DNAs (cpDNAs). Analysing 10 different genes and regions of Abies cpDNA PARDUCCI and SzMIDT (1999) were able to differentiate between a group of species A. alba, A. bornmülleriana, A. nordmanniana, A. cephalonica and A. cilicica growing in relatively adjacent regions of the Mediterranean basin and a group of species A. nebrodensis, A. numidica, A. pinsapo and $A$. concolor with a scattered and isolated occurrence in Sicily, North Africa, Iberian Peninsula and in North America, respectively. At the nucleotide sequence level IsODA et al. (2000b) revealed profound differences in the cpDNA trn $\mathrm{L}$ and trn $\mathrm{F}$ intergenic spacer region of 9 Asian, 2 Mediterranean and 6 North American species of firs. The authors stressed the importance of systematic studies of the genus Abies at the DNA level owing to the difficulties with its classification based on morphological traits.

In order to determine the extent of genetic variation within Abies on a broader scale, a comparative study of cpDNA restriction profiles was made involving 15 Asian, 6 North American and 7 Mediterranean species. This accounts for majority of the Abies representatives distributed in the respective regions of the world.

\section{Material and Methods}

\section{Plant material}

The list of species subjected to analysis of their cpDNAs together with their taxonomic status and geographic distribution is presented in Table 1. Each species was represented in the experiment by only one individual. The samples of $A$. alba

Table 1. - List of species investigated, their taxonomic classifications and geographic distribution.

\begin{tabular}{|c|c|c|c|c|}
\hline \multirow[t]{2}{*}{ Species } & \multirow{2}{*}{\begin{tabular}{|l} 
Liu (1971) \\
Section \\
\end{tabular}} & \multicolumn{2}{|c|}{ Farjon, Rushforth (1989) } & \multirow[t]{2}{*}{ Distribution } \\
\hline & & Section & Subsection & \\
\hline A. firma & Momi & Momi & Firmae & S. Japan \\
\hline A. holophylla & Homolepides & Momi & Holophyllae & N. China, Korea \\
\hline A. homolepis & Homolepides & Momi & Homolepides & C., S. Japan \\
\hline A. mariesii & Homolepides & Amabilis & & N., C. Japan \\
\hline A. kawakamii & Homolepides & Balsamea & Laterales & Taiwan \\
\hline A. chensiensis & Chensienses & Momi & Holophyllae & C., S. China \\
\hline A. fargesii & Elatiopsis & Pseudopicea & Delavayianae & China \\
\hline A. squamata & Elatiopsis & Pseudopicea & Squamatae & China \\
\hline A. delavayi & Elatiopsis & Pseudopicea & Delavayianae & China \\
\hline A. delavayi var. georgei & Elatiopsis & Pseudopicea & Delavayianae & China \\
\hline A. recurvata & Elatiopsis & Momi & Homolepides & China \\
\hline A. koreana & Elate & Balsameae & Medianae & Korean Penins. \\
\hline A. nephrolepis & Elate & Balsameae & Medianae & Korea, China \\
\hline A. sachalinensis & Elate & Balsameae & Medianae & Japan, Sachalin \\
\hline A. veitchii & Elate & Balsameae & Medianae & Japan \\
\hline A. procera & Nobiles & Nobilis & & W. USA \\
\hline A. magnifica & Nobiles & Nobilis & & W. USA \\
\hline A. concolor & Grandes & Grandis & & $\begin{array}{l}\text { W. USA, } \\
\text { Mexico }\end{array}$ \\
\hline A. grandis & Grandes & Grandis & & $\begin{array}{l}\text { W. USA, } \\
\text { Canada } \\
\end{array}$ \\
\hline A. amabilis & Grandes & Amabilis & & $\begin{array}{l}\text { W. USA, } \\
\text { Canada }\end{array}$ \\
\hline A. lasiocarpa & Balsameae & Balsamea & Laterales & $\begin{array}{l}\text { Canada, W. } \\
\text { USA }\end{array}$ \\
\hline A. alba & Abies & Abies & & C., S. Europe \\
\hline A. cephalonica & Abies & Abies & & Balcan Penins. \\
\hline A. nebrodensis & Abies & Abies & & Sicily \\
\hline A. nordmanniana & Abies & Abies & & Caucasus,Turkey \\
\hline A. cilicica & Piceaster & Abies & & Asia Minor \\
\hline A. pinsapo & Piceaster & Piceaster & & S. Spain \\
\hline A. numidica & Piceaster & Piceaster & & N. Algeria \\
\hline
\end{tabular}

and $A$. kawakamii were collected from the individuals in natural stands in Slovakia and in Taiwan, respectively. The samples of remaining species were derived from the specimen introduced to Arboretum Mlynany and Arboretum Kysihybel in Slovakia, to the „Arboretum Tannenhöft" at the Institute for Forest Genetics, Grosshansdorf in Germany and to the Hørsholm Arboretum in Denmark.

\section{DNA isolation, primer types and DNA amplification}

Total DNA was extracted from young needles using modified protocol of MURRAY and THOMPSON (1980) in which only $0.5 \mathrm{~g}$ of needles per individual were used instead of prescribed $10 \mathrm{~g}$ of needle material. This also reduced the amount of extracting buffer used ( $7 \mathrm{ml}$ instead of $200 \mathrm{ml}$ ).

Eight pairs of heterologous primers specific for the chloroplast genome were employed to amplify the corresponding cpDNA regions. The designation of the primers, their sequences and size are shown in Table 2. PCR was run in PTC200 Peltier Thermal Cycler (MJ Research). DNA amplification was performed at $94^{\circ} \mathrm{C}$ for $30 \mathrm{~s}$, followed by 34 cycles at $94^{\circ} \mathrm{C}$ for $30 \mathrm{~s}, 57^{\circ} \mathrm{C}$ for $30 \mathrm{~s}$, and $72^{\circ} \mathrm{C}$ for $1 \mathrm{~min}$. The last strand elongation at $72^{\circ} \mathrm{C}$ required an additional $2 \mathrm{~min}$. To confirm successful amplification and to determine the size of the amplified fragment, $2 \mu \mathrm{l}$ of the PCR products were separated by electrophoresis in $1 \%$ agarose gel containing ethidium bromide (125 $\mathrm{ng}$ per $250 \mathrm{ml}$ of gel mixture), in 1x TBE. The DNA fragments were visualized by UV fluorescence.

\section{DNA digestion}

The PCR products obtained with all the 8 primers were digested with the restriction enzymes Dra I, Hind III, Vsp I, Taq I, Tru1l, Hae III, Msp I, Hinf I, Hpa II and Cfr 131, respectively. Of the total PCR amplification volume, $6 \mu$ of the PCRproduct was digested by 5 units of restriction nuclease following manufacturer's instruction (MBI Fermentas, Promega). The cpDNA fragments were fractionated electrophoretically in $2 \%$ agarose gel with ethidium bromide (125 $\mathrm{ng}$ per $250 \mathrm{ml}$ of gel mixture) and 1x TBE buffer. Electrophoresis was run at $6 \mathrm{~V} / \mathrm{cm}$ for 3.5 hours. Separated fragments were visualized by UV fluorescence. The size of individual fragments was estimated by comparison with a molecular standard (GeneRuller ${ }^{\mathrm{TM}} 100$ bp DNA Ladder Plus, MBI Fermentas).

\section{Data analysis}

Of the 80 digestions performed only 15 primer-enzyme combinations revealing polymorphism were taken into account when constructing a cladogram (Table 3). Variants of the restriction site were recorded as the presence (1) versus the absence $(0)$ of the restriction site at the corresponding fragment. Phylogenetic relationships among Abies species were reconstructed by both UPGMA (unweighted pair-group method average) on the basis of Nei's genetic distance and Wagner parsimony method (PHYLIP v3.5c; FELSENSTEIN, 1993). Statistical tests of the topology on the phylogenetic tree were performed with 100 bootstrapped samples (FELSENSTEIN, 1993).

\section{Results}

Each of the 8 pairs of primers used efficiently amplified the corresponding cpDNA regions in all the 28 Abies species investigated. The approximate size of the PCR products ranged between $1200 \mathrm{bp}\left(r p l_{2}\right)$ and $2854 \mathrm{bp}\left(\mathrm{rpoC}_{1}\right.$, Table 2). No variation in size of PCR products was observed between individual species in $1 \%$ agarose gel. Sumarilly the results of the restriction analysis are presented in Table 3.

A considerable restriction site divergence was observed between individual species or groups of species, but most con- 
Table 2. - DNA sequences of the primers used and the size of the corresponding PCR products.

\begin{tabular}{|c|c|c|c|}
\hline Primer pair & Sequence & Size (bp) & Source \\
\hline \multirow[t]{2}{*}{$C \mathrm{p}-r b c \mathrm{~L}_{1}-r b c \mathrm{~L}_{2}$} & 5'-TGTCACCAAAAACAGAGACT-3’ & \multirow{2}{*}{1387} & \multirow{2}{*}{ HIPKINS et al., 1990} \\
\hline & 5'-TTCCATACTTCACAAGCAGC-3' & & \\
\hline \multirow[t]{2}{*}{ Cp-trnS-psbC } & 5'-GTTTGGAATCCCTCTCTCTC-3` & \multirow{2}{*}{1561} & \multirow{2}{*}{ DEMESURE et al., 1995} \\
\hline & 5'-GGTCGTGACCAAGAAACCAC-3' & & \\
\hline \multirow{2}{*}{$\mathrm{Cp}-t r n \mathrm{~L}-t r n \mathrm{~V}$} & 5'-CTGCTTCCTAAGAGCAGCGT-3' & \multirow{2}{*}{2234} & \multirow{2}{*}{ WANG et al., 2000} \\
\hline & 5-TTGACATGGTGGAAGTCATCA-3' & & \\
\hline \multirow[t]{2}{*}{ Cp-trnK } & 5'-AACCCGGAACTAGTCGGATG-3' & \multirow{2}{*}{2569} & \multirow{2}{*}{ HIRATSUKA et al., 1989} \\
\hline & 5'-TCAATGGTAGAGTACTCGGC-3' & & \\
\hline \multirow[t]{2}{*}{ Cp-rpo $\mathrm{C}_{1}$} & 5'-TCGATTGAAACGAGTACGACC-3' & \multirow{2}{*}{2854} & \multirow{2}{*}{ PARDUCCI and SZMIDT, 1999} \\
\hline & 5'-CACTGGAGGGCCAATACCTA-3' & & \\
\hline \multirow[t]{2}{*}{ Cp-rpl $l_{2}$} & 5'-AAAGGTCGTAATGCCAGAGGAAT-3' & \multirow{2}{*}{1200} & \multirow{2}{*}{ GRAHAM and OLMSTEAD, 2000} \\
\hline & 5'-TTCCAAGYGCAGGATAACCCCA-3’' & & \\
\hline \multirow[t]{2}{*}{ Ср-psbB } & 5-ATGGTTTTGCCTTGGTATCGTGTTCATAC-3 & \multirow{2}{*}{1350} & \multirow{2}{*}{ WANG et al., 2000} \\
\hline & 5-CCAAAAGTRAACCAACCCCTTGGAC-3' & & \\
\hline \multirow[t]{2}{*}{$\mathrm{Cp}-p s b \mathrm{D}$} & 5'-ATGACTGGTTACGRAGGGACCA-3' & \multirow[t]{2}{*}{1230} & \multirow{2}{*}{ WANG et al., 2000} \\
\hline & 5'-CATAACCRAAGAAKGGAAAAGAATC-3' & & \\
\hline
\end{tabular}

Note: $\mathrm{K}$ stands for $\mathrm{G}$ or $\mathrm{T}$

$R$ stands for $A$ or $G$

Table 3. - Restriction fragment phenotypes used to infer site mutations.

\begin{tabular}{|c|c|c|c|c|c|c|c|c|c|c|c|c|c|c|c|}
\hline Primer & & సें & & & & 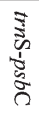 & 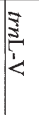 & & 亲 & & &  & $\frac{2}{2}$ & & $\begin{array}{l}8 \\
2 \\
2\end{array}$ \\
\hline Restriction enzyme & প্2 & 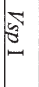 & $\mathbb{Z}$ & & $\vec{z}$ & $\mid \begin{array}{l}\mathbb{Z} \\
\mathbb{E} \\
\Xi\end{array}$ & 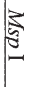 & $\mathbb{Z}$ & 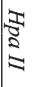 & $\vec{\Xi}$ & & 疋 & $\frac{3}{2}$ & $\stackrel{\uparrow}{\omega}$ & \\
\hline Asian firs & & & & & & & & & & & & & & & \\
\hline A. firma & 0 & 1 & 1 & 1 & 0 & 1 & 1 & 1 & 1 & 0 & 1 & 0 & 0 & 1 & \\
\hline A. holophylla & 0 & 1 & 1 & 1 & 0 & 1 & 1 & 1 & 1 & 0 & 1 & 0 & 0 & 0 & 0 \\
\hline A. homolepis & 0 & 1 & 1 & 1 & 0 & 1 & 1 & 1 & 1 & 0 & 1 & 0 & 0 & 0 & 0 \\
\hline A. mariesii & 0 & 0 & 0 & 1 & 0 & 1 & 0 & 1 & 1 & 0 & 1 & 0 & 0 & 0 & 1 \\
\hline A. kawakamii & 0 & 1 & 1 & 1 & 0 & 1 & 1 & 1 & 1 & 0 & 1 & 0 & 0 & 0 & 0 \\
\hline A. chensiensis & 0 & 1 & 1 & 1 & 0 & 1 & 1 & 1 & 0 & 0 & 1 & 0 & 0 & 0 & 0 \\
\hline A. fargesii var. faxoniana & 0 & 1 & 1 & 1 & 0 & 1 & 1 & 1 & 1 & 0 & 1 & 0 & 0 & 0 & 0 \\
\hline A. squamata & 0 & 1 & 1 & 1 & 0 & 1 & 1 & 1 & 1 & 0 & 1 & 0 & 0 & 0 & 0 \\
\hline A. delavayi & 0 & 1 & 1 & 1 & 0 & 1 & 1 & 1 & 1 & 0 & 1 & 0 & 0 & 0 & 0 \\
\hline A. delavayi var. georgei & 0 & 1 & 1 & 1 & 0 & 1 & 1 & 1 & 1 & 0 & 1 & 0 & 0 & 0 & 0 \\
\hline A. recurvata & 0 & 1 & 1 & 1 & 0 & 1 & 1 & 1 & 1 & 0 & 1 & 0 & 0 & 0 & 0 \\
\hline A. koreana & 0 & 1 & 1 & 1 & 0 & 1 & 1 & 1 & 1 & 1 & 1 & 0 & 0 & 0 & 0 \\
\hline A. nephrolepis & 0 & 1 & 1 & 1 & 0 & 1 & 1 & 1 & 1 & 1 & 1 & 0 & 0 & 0 & 0 \\
\hline A. sachalinensis & 0 & 1 & 1 & 1 & 0 & 1 & 1 & 1 & 1 & 1 & 1 & 0 & 0 & 0 & 0 \\
\hline A. veitchii & 0 & 1 & 1 & 1 & 0 & 1 & 1 & 1 & 1 & 1 & 1 & 0 & 0 & 0 & 0 \\
\hline North Americ: & & & & & & & & & & & & & & & \\
\hline A. procera & 0 & 0 & 0 & 0 & 0 & 1 & 0 & 1 & 1 & 0 & 1 & 0 & 0 & 0 & 1 \\
\hline A. magnifica & 0 & 0 & 1 & 0 & 0 & 1 & 0 & 1 & 1 & 0 & 1 & 0 & 0 & 0 & 1 \\
\hline A. concolor & 0 & 0 & 1 & 0 & 0 & 1 & 0 & 1 & 1 & 0 & 1 & 1 & 0 & 0 & 1 \\
\hline A. grandis & 0 & 0 & 0 & 1 & 1 & 1 & 0 & 1 & 1 & 0 & 1 & 1 & 0 & 0 & 1 \\
\hline A. amabilis & 0 & 0 & 0 & 1 & 1 & 1 & 0 & 1 & 1 & 0 & 1 & 1 & 0 & 0 & 1 \\
\hline A. lasiocarpa & 0 & 1 & 1 & 1 & 0 & 1 & 1 & 1 & 1 & 0 & 0 & 0 & 0 & 0 & 1 \\
\hline Mediterranean firs & & & & & & & & & & & & & & & \\
\hline A. alba & 1 & 0 & 0 & 0 & 0 & 0 & 1 & 0 & 1 & 0 & 1 & 0 & 1 & 1 & 1 \\
\hline A. cephalonica & 1 & 0 & 0 & 0 & 0 & 0 & 1 & 0 & 1 & 0 & 1 & 0 & 1 & 1 & 1 \\
\hline A. nebrodensis & 1 & 0 & 0 & 0 & 0 & 1 & 1 & 0 & 1 & 0 & 1 & 0 & 1 & 1 & 1 \\
\hline A. nordmanniana & 1 & 0 & 0 & 0 & 0 & 0 & 1 & 0 & 1 & 0 & 1 & 0 & 1 & 1 & 1 \\
\hline A. cilicica & 1 & 0 & 0 & 0 & 0 & 0 & 1 & 0 & 1 & 0 & 1 & 0 & 1 & 1 & 1 \\
\hline A. pinsapo & 1 & 0 & 0 & 0 & 0 & 1 & 1 & 0 & 1 & 0 & 1 & 0 & 1 & 1 & 1 \\
\hline A. numidica & 1 & 0 & 0 & 0 & 0 & 0 & 1 & 0 & 1 & 0 & & 0 & 1 & & \\
\hline
\end{tabular}

spicuous was the difference between the Asian and North American firs on the one hand and Mediterranean firs on the other hand. The absence of Dra I restriction site in the $r b c \mathrm{~L}_{1}$ $r b c \mathrm{~L}_{2}$ region of the former group has, as a rule, contrasted with its presence in the latter one. The same was true of the $\mathrm{rpl}_{2} / \mathrm{Msp}$ I probe-enzyme combination and also partially in the $p s b \mathrm{D} / C f r 131$ combination. However, in case of $p s b \mathrm{D} / C f r 131$ the differences in position of restriction sites instead of their complete absence were responsible for the differentiation between these groups of species. The Asian species A. firma shared identical restriction sites $p s b \mathrm{D} / C f r \quad 131$ with the Mediterranean firs. A clearcut difference between the Mediterranean firs and a group of Asian and North American firs was also found in the Hinf I restriction sites of the trn $\mathrm{K}$ region.

Contrary to the observation described above, there were restriction site variants in the combinations $r b c \mathrm{~L}_{1}-r b c \mathrm{~L}_{2} / V s p \mathrm{I}$ and $p s b \mathrm{~B} / M s p \mathrm{I}$, which differentiated the Asian species from the North American and Mediterranean firs. The only exceptions were the Asian species A. mariesii and the North American species A. lasiocarpa. The former shared the same restriction sites for both primer-enzyme combinations as the Mediterranean species, whereas the latter possessed the identical restriction sites with the Asian species but only for the combination of $r b c \mathrm{~L}_{1}-r b c \mathrm{~L}_{2} / V s p \mathrm{I}$.

Of the three groups of Abies species studied, the Mediterranean firs exhibited the lowest level of polymorphism. Except for a combination of trnS-psbC/HaeIII, no restriction site variant was observed among Mediterranean firs in 14 of the 15 analyzed primer-restriction enzyme combinations. The species A. nebrodensis and A. pinsapo shared the same restriction sites of $t r n \mathrm{~S}-p s b \mathrm{C} / \mathrm{Hae} \mathrm{III}$ as the Asian and North American species.

A limited number of restriction site variants were observed among the Asian species, where 8 of the 15 species showed an identical haplotype. Six of the 10 restriction site variants, observed among the Asian species, were observed only in a single species, A. mariesii. Four species of the section Elate (A. koreana, A. nephrolepis, A. sachalinensis, A. veitchii) showed a unique restriction site for a combination of $r p o \mathrm{C}_{1} / T a q \mathrm{I}$ compared to the other species. In combination $\operatorname{trn} \mathrm{K} / \mathrm{HpaII}$, a complete absence of restriction site was observed only in A. chensiensis. This may be used as a genetic marker for identification of the species provided more individuals of the species are subjected to analysis to rule out the intraspecific variation. Compared to other Asian species, A. firma showed a unique restriction site variant for a combination of $p s b \mathrm{D} / C f r 131$, which was identical with that observed in the Mediterranean species.

In comparison with the Mediterranean and Asian firs, the North American species were much more heterogeneous. Especially divergent was the species A. lasiocarpa of the section Balsameae possessing unique restriction site variants of $t r n \mathrm{~L}$ -

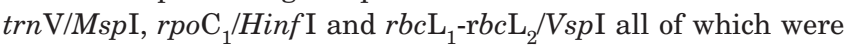
found to be monomorphic in the rest of the North American species. The species-specific variants $\operatorname{trn} \mathrm{K} / \operatorname{Hinf} \mathrm{I}$ and $r p o \mathrm{C}_{1} /$ TaqI were also revealed in A. procera. Based on the rpo $\mathrm{C}_{1}$ / $M s p \mathrm{I}$ and $\mathrm{rpoC}_{1} / \mathrm{Hinf} \mathrm{I}$ restriction site variants, a group of species A. concolor, A. grandis and A. amabilis of the section Grandes was distinguished from the other species analyzed so far. Within the section Grandes, only A. grandis and A. amabilis showed the identical restriction site variant of trnS$p s b \mathrm{C} / T a q \mathrm{I}$ combination differing from the rest of the species. Both the above species shared identical restriction site variant trn S-psbC/Tru1l with the Asian species A. mariesii.

Based on the observed restriction site changes among species, a phylogenetic relationship among Abies species has been constructed (Fig. 1). The three global groups of Abies taxa have accordingly been recognized corresponding to the Asian, North American and Mediterranean firs. A group of the 4 Asian 




Figure 1. - The single most parsimonious tree derived from Wagner parsimony analysis.

species of the section Elate (A. veitchii, A. sachalinensis, A. koreana, A. nephrolepis) together with $A$. chensiensis of the section Chensienses and A. firma of the section Momi were most divergent from the Mediterranean species. Abies lasiocarpa of the section Balsameae has also deviated profoundly from the rest of the North American species suggesting its close relationship with the Asian species. Conversely, the Asian species A. mariesii showed the least divergence from the hypothetical ancestor compared to other Asian species suggesting a close relationship with the North American species. This might be caused by 6 unique restriction site variants observed only in $A$. mariesii among the Asian species. Of these, 5 variants were shared with the North American species A. procera. In general, the Asian species were the least differentiated from each other. Although phylogenetic resolution among species was very low, the species of most sections formed distinct groups on a cladogram. The only exceptions were the sections Homolepides and Elatiopsis which were grouped together. The species in the North American group were most diversified from each other. This resulted in a low degree of concordance between the restriction profiles and taxonomic status of the species investigated. Among the representatives of the section Grandes, A. grandis and $A$. amabilis showed identical restriction profiles while $A$. concolor differed by 4 restriction site variants. Two species of the section Nobiles (A. procera, A. magnifica) differed by 3 restriction site changes from each other.

Contrary to the North American firs, phylogenetic reconstruction among the Mediterranean firs revealed the least differentiation among them and a low degree of concordance between the restriction profiles and taxonomic status of the species. An overwhelming majority of these species were grouped together. However, 2 species belonging to the different sections but showing identical restriction profiles (A. nebrodensis, A. pinsapo) were grouped together. There was a single restriction site change between these species and the rest of Mediterranean firs.

\section{Discussion}

In spite of postulated conservative nature of the gene-coding regions, the conifer cpDNA was found to harbour a large amount of variation in its intron and spacer regions (IsODA et al., 2000). This makes the analysis of cpDNA variation useful for phylogenetic studies between species. In Abies, the multiple variable regions are believed to be scattered throughout the whole genome (PARDUCCI and SzMIDT, 1999). Several attempts to characterize such variation in the genus Abies using PCRRFLP approach have been attempted in recent years (TSUMURA et al., 1995, 2000; Ziegenhagen and Fladung, 1997; PARDUCCI and SzMIDT, 1999). The results showed unequivocally the variable nature of Abies cpDNA especially at the species level. However, within-species variation has also been documented in A. alba, A. mariesii and A. sachalinensis (ZIEGENHAGEN and Fladung, 1997; Tsumura et al., 1994; HAYASHI et al., 2000). This aspect should be kept in mind when interpreting the results of presented study involving only 1 specimen of each species investigated. Previous studies on Abies species have been focused on the species of only one region or continent. Accordingly, Tsumura et al. (1995) failed to detect any variation within 6 genes of cpDNA among the species A. mariesii, $A$. sachalinensis, A. homolepis and A. veitchii. These representatives of the genus Abies in Japan formed one cluster on a phylogenetic tree diverging considerably from the representatives of several other genera of Pinaceae. PARDUCCI and SzMIDT (1999) included eight Mediterranean species and one North American species in their study. It was only the North American species A. concolor which exhibited the most diverged haplotype among the species analysed. IsodA et al. (2000) subjected ten Asian, six North America and two Mediterranean species to sequence analysis of the intergenic spacer $\operatorname{trn} \mathrm{L}$ and $\operatorname{trn} \mathrm{F}$. The Mediterranean species, A. alba and A. nordmanniana were found to be the most differentiated from other species in their tandem repeat sequence. Therefore, it seems reasonable to assume that sampling of species from different parts of the world may contribute to recognizing more completely the extent of genetic differentiation within the genus Abies.

The results presented in this study proved the benefits of using a molecular approach in understanding species relatedness in the genus Abies. There was illustrated a unique genetic status of the Mediterranean firs conspicuously diverging from the Asian and North American firs. Independent clustering of A. nebrodensis and A. pinsapo within a group of Mediterranean firs was due to a single variation in their trnS- $p s b \mathrm{C}$ region revealed by HaeIII. It is interesting to mention in this connection that no variation of this kind was detected among Asian and North American firs. All the specimen were characterized by the G4 haplotype only, based on the classification by ZIEGENHAGEN and FLADUNG (1997). Unfortunately, we were unable to confirm the differentiation among the Mediterranean species which was reported by PARDUCCI and SzMIDT (1999). Different primers and restriction enzymes used in the respective studies may be one of the reasons for this discrepancy. Phylogenetic relationships among the Mediterranean firs constructed on the basis of cpDNA mutations agree with the ample evidence concerning mutual crossability of Abies species in the region (Rohmeder and Eisenhut, 1961; Greguss, 1984; Greguss and PAUle, 1989). On the contrary, the divergence of the Mediterranean firs from the North American species is also supported 
by the existence of a strong reproductive isolation between these groups of species, which was proved experimentally in both hybridological and embryological studies (KORMUTAK, 1985; KoRMUTAK et al., 2002).

When the phylogenetic tree was rooted by a pair of $A$. nebrodensis and $A$. pinsapo species both of which were most distantly related to other operational taxonomic units (OTUs) in the unrooted dendrogram constructed with unweighted pair-group method using averages-UPGMA (figure not presented), the clade leading to the North American and Asian species was significantly similar (confidence interval of $100 \%$ ). This suggests a monophyletic origin of both North American and Asian firs. Apparently, they have evolved from the same hypothetical ancestor, probably from one of the Mediterranean firs. The cladogram also indicates that North American species diverged first from the Mediterranean firs before their divergence from the Asian species.

Regarding unusual phylogenetic topologies of $A$. mariesii and A. lasiocarpa, a strong support for validity of our finding has been provided by the sequence analysis data of cpDNA by IsODA et al. (2000a). Based on DNA sequence analysis of 3 cpDNA spacer regions in 15 Abies species, the authors concluded that origin of $A$. mariesii might be different from the other four Japanese species. This Asian species showed a close relationship with the North American species A. balsamea and $A$. lasiocarpa as well as with the Asian species A. holophylla, A. koreana, $A$. nephrolepis and A. sibirica. The authors proposed that the divergence of $A$. mariesii occurred together with the North American species A. concolor and A. grandis in the early stage of Abies evolution. However, with regard to the observed phylogenetic status of $A$. mariesii, which according to our data was included into the North American group, the possibility of a recent introduction of the species from North America into Asia (Japan) also could not be ruled out. More careful taxonomic consideration is required to verify this hypothesis.

Among the North American firs, A. lasiocarpa turned out to be most divergent from the rest, which resulted in the closest phylogenetic relationship with the Asian firs. Although the confidence interval $(80 \%)$ was not high enough to hypothesize that the origin of A. lasiocarpa and the Asian firs was monophyletic, there might be still relatively strong possibility that it has evolved from the same ancestor. The most divergent topology of A. lasiocarpa from the rest of the North American species is also in accordance with hybridological data by HAWLEY and DEHAYES (1985) who postulated the incompatible nature of the interspecific cross between $A$. concolor and A. lasiocarpa. Conversely, the interspecific combinations $A$. procera $\times$ A. magnifi$c a, A$. procera $\times$ A. grandis, $A$. procera $\times$ A. concolor, $A$. amabilis $\mathrm{x} A$. grandis and $A$. amabilis $\mathrm{x} A$. concolor were reported to be compatible (MERGEN et al., 1964, 1968; GAUDLITZ, 1983, 1985; CRITCHFIELD, 1988).

There were 3 subgroups recognized among the North American species, which represented a more profound diversification within this group of species as compared to the Mediterranean species. However, judging from the levels of the confidence limits on each node, they were not divergent enough to be grouped as independent clades. Overall phylogenetic relationships among the North American firs revealed that there was discrepancy between cpDNA patterns and taxonomic classification of the species in this region. For example, A. concolor and $A$. grandis which intercross spontaneously in a zone of their sympatry in western part of USA, were the closest ones and differed by 4 restriction site changes (HARLOW and HARRAR, 1958; HAMRICK and LIBBY, 1972). A high genetic affinity between these species was also proved by successful attempts with their artificial hybridization (LARSEN, 1934; ROHMEDER, 1960;
KLAeHN and WINIESKI, 1962; KANTOR and CHIRA, 1971, 1972; CRITChField, 1988; Kobliha, 1994). Although based on 1 specimen only the four restriction site variants observed between $A$. concolor and A. grandis (trnS-psbC/Tru1l, trnL-trnV/Rsa I, $r b c \mathrm{~L}_{1}-r b c \mathrm{~L}_{2} /$ Hind III, $r p l_{2} /$ Tru1l) offer the possibility for identification of parental species and hybrid individuals within sympatric area.

Regarding the Asian species, our results only partially correlated with the nucleotide sequence data of ISODA et al. (2000b). The authors found the same tandem repeats in the cpDNA spacer region between $\operatorname{trn} \mathrm{L}$ and $\operatorname{trn} \mathrm{F}$ genes in A. koreana, A. nephrolepis, A. sachalinensis, A. veitchii, A. densa, A. sibirica, A. firma and A. homolepis belonging taxonomically to the sections Elate, Pichta, Momi and Homolepides, respectively. Only A. holophylla and A. mariesii of the section Homolepides differed in this respect. Our data confirmed differentiation between the Asian species according to the sections. The only exceptions were the species of the section Elatiopsis (A. recurvata, A. delavayi, A. delavayi var. georgei, A. squamata) and Homolepides (A. kawakamii, A. holophylla, A. homolepis) occupying common position on a cladograme. However, the branching patterns of the Asian species is based on single restriction site changes only suggesting close genetic relationships among them. A considerable differentiation of A. firma from $A$. homolepis and $A$. veitchii has been recently reported by IsODA and SHIRAISHI (2001) based on the nuclear-encoded Gap gene. Available hybridological data also indicate extensive hybridization among Asian species irrespective of their taxonomic status (Husao and Kenichi, 1951; Klaehn and Winieski, 1962; MerGEN et al., 1964, 1988; ISODA and SHIRAISHI, 1999; IsodA et al., 2000; IIZUKA et al., 2000).

In the light of recent taxonomic divisions of the genus Abies, it seems unjustified the placement of $A$. koreana, $A$. nephrolepis, A. sachalinensis and $A$. veitchii into the section Balsameae and A. homolepis and A. holophylla into the section Momi as proposed by FARJON and RUSHFORTH (1989). There is a much higher degree of consistency between our results and the taxonomic account of the genus given by LIU (1971). However, additional comprehensive data on the morphological traits, crossability and molecular information should be necessary to make a responsible decision about modification of the Abies taxonomy in future.

\section{Conclusion}

Presented results of PCR-based restriction analysis of cpDNA in 28 representatives of the genus Abies provided evidence which supports the heterogeneous nature of the genus. This is in contradiction with the concept postulating close genetic affinity between Abies species. The divergence of the Mediterranean species from both Asian and North American firs already documented from hybridological studies has been confirmed at the molecular level. A group of the Mediterranean firs has accordingly been shown to involve genetically closely related species. The Asian firs exhibited more complex branching patterns, whereas the North American firs revealed the highest degree of genetic diversification among species. The unusual topologies of the Asian species A. mariesii and the North American species A. lasiocarpa observed in the this study need to be verified.

\section{Acknowledgements}

The authors thank the Korea Institute of S \& T Evaluation and Planning for providing a visiting fellowship to Dr. KoRMUTAK during the course of study. This study was supported by the Korea Forest Research Institute and partially also by the Slovak Grant Agency VEGA, project no. 2/3192/23. 


\section{References}

CRitchfield, W. B. (1988): Hybridization of the California firs. Forest Science 34: 139-151.

Demesure, B., Sodzi, N. and Petit, R. J. (1995): A set of universal primers for amplification of polymorphic non-coding regions of mitochondrial and chloroplast DNA in plants. Molecular Ecology 4: 129-131.

FARJON, A. and RUShForth, K. D. (1989): A classification of Abies Miller (Pinaceae). Notes of the Royal Botanic Garden, Edinburgh 46: 59-79.

FeLsenstein, J. (1993): PHYLIP (Phylogeny Inference Package) version 3.5c. Distributed by the author. Department of Genetics. University of Washington. Seattle, WA. USA.

GAUDLITZ, G. VON (1983): Untersuchungen zur Diagnose und Charakterisierung von Tannen-Bastarden. Dissertation zur Erlangung des Doktorgrades der Forstwissenschaftlichen Fakultät der Ludwig-Maximilian-Universität München, München, $137 \mathrm{pp}$.

Graham, S. W. and Olmstead, R. G. (2000): Utility of 17 chloroplast genes for inferring the phylogeny of the basal angiosperms. American Journal of Botany 87: 1712-1730.

GREGUSS, L. (1984): The results of species hybridization within the genus Abies. Forest Research News (Forest Research Institute in Zvolen) 1: 10-16.

Greguss, L. and PAule, L. (1989): Artificial hybridization in the genus Abies. In: Proceeding of the $5^{\text {th }}$ IUFRO-Tannensymposium, Eds. PaUle, L. and KorPel, S. pp. 179-188, Hochschule für Forstwirtschaft und Holztechnologie, Zvolen.

HAMRICK, J. L. and LiBBY, W. J. (1972): Variation and selection in western U.S. montane species. I. White fir. Silvae Genetica 21: 29-36.

HARLOW, W. M. and HARRAR, E. S. (1958): Textbook of Dendrology. Fourth Edition. McGraw-Hill Book Company, Inc., New York-Toronto-London, pp. 169-193.

Hawley, G. J. and DeHaYES, D. H. (1985): Hybridization among several North American firs. I. Crossability. Canadian Journal of Forest Research 15: 42-49.

Hayashi, E., Ubukata, M., IizuKa, K. and Itahana, N. (2000): Genetic differentiation of organelle DNA polymorphisms in Sakhalin fir from Hokkaido. Forest Genetics 7 (1): 31-38.

Hipkins, V. D., Tsai, C. H. and Strauss, S. H. (1990): Sequence of the gene for large subunit of ribulose 1,5-biphosphate carboxylase from a gymnosperm, Douglas fir. Plant Molecular Biology 15: 505-507.

Hiratsuka, J., Shimada, H., Whittier, R., Ishibashi, T., Sakamoto, M., Mori, M., Kondo, C., Honji, Y., Sun, C. R., Meng, B. Y., Li, L. Q., Kanno, A., Nishizawa, Y., Hirai, A., Shinozaki, K. and Sugiura, M. (1989): The complete sequence of the rice (Oryza sativa) chloroplast genome: intermolecular recombination between distinct tRNA genes accounts for a major plastid DNA inversion during the evolution of cereals. Molecular Genes and Genetics 217: 185-194.

Husao, Y. and Kenichi, H. (1951): On interspecific hybrid Abies mayriana x Abies homolepis. Report of Sapporo Breeding and Forest Experiment Station 69: 63-80.

IIzUKA, K., NishiokA, T. and Kono, K. (2000): Basic density and duration of bud opening in the interspecies of Abies sachalinensis $\times$ A. homolepis and A. sachalinensis $\times$ A. veitchii. Journal of the Japanese Forestry Society 82 (2): 196-199.

IsODA, K. and SHIRAISHI, S. (1999): Identification of chloroplast DNA haplotypes of Abies firma and A. homolepis using a polymerase chain reaction with species-specific primers. Journal of Forest Research 4: 291-294.

Isoda, K., Shiraishi, S, Watanabe, S. and Kitamura, K. (2000): Molecular evidence of natural hybridization between Abies veitchii and $A$. homolepis (Pinaceae) revealed by chloroplast, mitochondrial and nuclear DNA markers. Molecular Ecology 9: 1965-1974.

IsODA, K., ShIRAIShI, S. and KISANUKI, H. (2000a): Systematic positions of Japanese firs in genus Abies (Pinaceae) revealed by using DNA sequencing of chloroplast spacer region and random amplified polymorphic DNAs (RAPDs) of nuclear DNA. Journal of the Japanese Forestry Society 82: 333-341.
Isoda, K., SHIRAISHI, S. and KisanUKI, H. (2000b): Classifying Abies species (Pinaceae) based on the sequence variation of a tandemly repeated array found in the chloroplast DNA trnL and $t r n \mathrm{~F}$ intergenic spacer. Silvae Genetica 49 (3): 161-165.

IsODA, K. and SHIRAISHI, S. (2001): Allelic sequence polymorphisms in the intron region of the nuclear-encoded Gap C gene preceded the speciation of three closely related Abies species (Pinaceae). Theoretical and Applied Genetics 102: 244-250.

KANTOR, J. and ChIRA, E. (1971): On the possibility of crossing of certain species of the genus Abies. Acta Universitatis Agriculturae (Brno), Series C 40 (1): 15-27.

KANTOR, J. and ChIRA, E. (1972): The results of some intra- and inter-specific crossings between the individuals of the genus Abies. Lesnictvi-Forestry 18 (6): 487-499.

Kiellander, C. L. (1962): Picea, Abies, Pseudotsuga. In: Handbuch der Pflanzenzüchtung, P. Parey, Berlin-Hamburg, pp. 854-873.

KLAeHN, F. V. and Winieski, J. A. (1962): Interspecific hybridization in the genus Abies. Silvae Genetica 11: 130-142.

KobliHA, J. (1994): Crossability of the hybrid Abies cilicica x Abies cephalonica with other species of the genus Abies. In: Breeding of Forest Trees in Changing Climatic Conditions. Ed. Longauer, R. pp. 51-54, Forest Research Institute, Zvolen.

KoRMUTAK, A. (1985): Study on species hybridization within the genus Abies. Acta Dendrobiologica, VEDA, Bratislava, 127 $\mathrm{pp}$.

Kormutak, A., Vookova, B. and Ziegenhagen, B. (2002): Reproductive isolation between Colorado white fir (Abies concolor) and the Mediterranean firs. Biologia, Bratislava 57 (4): 527-532.

LARSEN, C. S. (1934): Forest Tree Breeding. Royal Veterinary and Agricultural College Yearbook, Copenhagen, $106 \mathrm{pp}$.

LIU, T. S. (1971): A monograph of the genus Abies. Department of Forestry, College of Agriculture, National Taiwan University, Taipei, Taiwan, ROC, 608 pp.

Mergen, F., Burley, J. and Simpson, B. A. (1964): Artificial hybridization in Abies. Der Züchter 34: 242-251.

MurRAY, M. G. and Thompson, W. F. (1980): Rapid isolation of high molecular weight DNA. Nucleic Acid Research 8: 4231-4235

PARDUCCI, L. and SzMidT, A. E. (1999): PCR-RFLP analysis of cpDNA in the genus Abies. Theoretical and Applied Genetics 98: $802-808$.

RoHmeder, E. (1960): Bastardierung in der Gattung Abies. Silvae Genetica 9 (5): 136-137.

Rohmeder, E. and Eisenhut, G. (1961): Bastardierungsversuche in der Gattung Abies. Allg. Forstzeitschrift 16: 495-497.

SAX, K. and SAX, H. J. (1933): Chromosome number and morphology in the conifers. Journal of Arnold Arboretum 14: 356-375.

Tsumura, Y., TAguchi, H., Suyama, Y. and OHBA, K. (1994): Geographic cline of chloroplast DNA variation in Abies mariesii. Theoretical and Applied Genetics 89: 922-926.

Tsunura, Y., Yoshimura, K., TOMaru, N. and OHBa, K. (1995): Molecular phylogeny of conifers using RFLP analysis of PCR-amplified specific genes. Theoretical and Applied Genetics 91: 1222-1236.

TSumura, Y., Suyama, Y. and Yoshimura, K. (2000): Chloroplast DNA inversion polymorphism in populations of Abies and Tsuga. Molecular and Biological Evolution 17 (9): 1302-1312.

Wang, X. R., Szmidt, A. E. and NGuYng, H. N. (2000): The phylogenetic position of the endemic flat-needle pine Pinus krempfii (Pinaceae) from Vietnam, based on PCR-RFLP analysis of chloroplast DNA. Plant Systematics and Evolution 220: 21-36.

Ziegenhagen, B. and Fladung, M. (1997): Variation in the $p s b \mathrm{C}$ gene region of gymnosperms and angiosperms as detected by a single restriction site polymorphism. Theoretical and Applied Genetics 94: 1065-1071. 